\title{
Crónica
}

\section{Catálogo de publicaciones OPS}

La Organización Panamericana de la Salud presenta el Catálogo de Publicaciones 2009 en formato electrónico en línea: http://publications.paho.org/ spanish y en el lado derecho de la columna verá la imagen del catálogo de publicaciones 2009, seleccione ese enlace para transferir el catálogo en formato PDF a su computador.
A partir de 2009 se ha decidido que el Catálogo de Publicaciones de la OPS se distribuirá únicamente en formato electrónico, de manera tal que los usuarios en los diferentes países puedan reproducirlo localmente. Como indica la directora en la carta introductoria del catálogo: "Esta iniciativa se orienta a la defensa del medio ambiente, específicamente a la reducción de la tala de árboles para producción de papel”. 